\title{
A Study of Changes in Production by Domestic Broadcasters Using Virtual Studio
}

\author{
Jun-Sang Lee, Sung-Dae Park, Kim Cheeyong, Member, KIMICS
}

\begin{abstract}
This paper is for investigation and analysis of how a visual studio is widely used by domestic broadcasting companies and broadcasting companies' production environment. The history of a visual studio goes back to start of computer graphic. A visual studio is a way to produce a program using graphic sets created by a computer rather than actual setting, and it allows to express beyond limitations of actual studio settings and various imagery visual effects can be created by a computer. A visual studio can create 3-dimensional graphic and these graphics can be inter-locked with actual camera images to make visual spaces for various programs. These flows are aiming to achieve very natural image which is hard to distinguish it is artificially created rather than just to produce programs with simple image synthesis, and this paper analyzes the producing changes of domestic broadcasting visual studios as well as its usage and suggests the idealist direction for developing the production.
\end{abstract}

Index Terms - Virtual Studio, Camera Tracking, Chroma Keyer

\section{INTRODUCTION}

Due to development of digital technologies, the society and individuals are required to create diverse cultures. In an effort to produce diverse contents, virtual studios have been introduced in broadcasting images. However, there were almost no theoretical or practical data related to high costs, arrangement of professionals and production processes and environment, so virtual studios haven't been provided rapidly. During the black and white times when TV broadcasting was first created, images taken by cameras were fused with other images[1].

As the TV began to show color films, images were fused so that two cameras could shoot same images by applying moves of a camera to another camera beyond simply fusing images. Up-to-date graphic technologies are used to produce a virtual studio. Each broadcasting company has tried to develop different equipment and

\footnotetext{
Manuscript received December 30, 2010; revised February 1, 2011; accepted February 7, 2011.

Jun-Sang Lee is with Graduate School of Digital Media Engineering, Dong-Eui University, Busan, 614-714, Korea

(Email: junsang75@nate.com)

Sung-Dae Park is with Dept. of Digital Contents Engineering, DongEui University, Busan, 614-714, Korea(Email: sdpark@deu.ac.kr)

Corresponding author : Kim Cheeyong is with Dept. of Visual Information Engineering, Dong-Eui University, Busan, 614-714, Korea (Email:kimchee@deu.ac.kr)
}

graphic technologies[2].

As a virtual studio is linked to a camera tracking sensor, it used the production environment of a real-time rendering machine and diverse studies have been attempted about types of each sensor, its operation principles and operation methods.

The Blue Studio production environment consisting of ways to establish a Blue Screen which is the basic environment and setting about lighting is a basic condition which a virtual studio should have[3]. Information which we obtain through our eyes are changing into super-space 3D images beyond time and space owing to its operation system[4],[5]. Considering that broadcasting and cinema have expressed illusions and real images, virtual studios are expected to be utilized in more diverse ways.

A virtual studio is better than a physical set in that it can keep virtual sets designed with computer graphic and can be taken out real time whenever they are necessary. Such virtual expression use data made with $3 \mathrm{D}$ graphic. In broadcasting programs, virtual set design should be used following broadcasting contents and the images can be different depending on purposes to use them. This study is aimed at suggesting directions for the future of a virtual studio and preparing a frame of understanding through analyzing domestic production environment and cases.

\section{RELATED STUDIES}

A virtual studio is where computer graphic technologies and broadcasting equipment meet. The setting of a virtual studio looks very complicated, but it consists of a few devices. Components of a virtual studio are a camera tracking system, Chroma studio, Chroma keyer and workstation. Only when these conditions are satisfied, the virtual studio can be operated to satisfy common conditions of each device,

\section{A. Camera Tracking System}

A camera tracking system is important to get movements of a camera[6]. Camera tracking techniques are to capture real location values and movements of a camera real time while shooting[7]. This system traces values meaning values of camera lenses, motion values like pan and tilt, camera angles including ROLL, X, Y and $\mathrm{Z}$ and spacious locations. 
TABLE

COMPARISON DEPENDING ON WAYS OF

CAMERA TRACKING

\begin{tabular}{|c|c|c|c|}
\hline Division & Manual & $\begin{array}{l}\text { Infrared Ray } \\
\text { Type }\end{array}$ & $\begin{array}{l}\text { Software } \\
\text { Type }\end{array}$ \\
\hline $\begin{array}{l}\text { Mechanical } \\
\text { Zoom, Focus } \\
\text { Devices }\end{array}$ & Necessary & $\begin{array}{c}\text { Necessary } \\
\text { (Mechanic devices } \\
\text { are necessary) }\end{array}$ & Unnecessary \\
\hline Pan/Tilt Possible & Possible & Possible & Possible \\
\hline Dolly/Track & $\begin{array}{c}\text { Possible (Possible at } \\
\text { Robotics) }\end{array}$ & Possible & Possible \\
\hline $\begin{array}{c}\text { Shooting } \\
\text { Possible Angles }\end{array}$ & Unlimited & Unlimited & $\begin{array}{l}\text { Decided by a patter } \\
\text { and generally } 150^{\circ}\end{array}$ \\
\hline $\begin{array}{l}\text { Hardware } \\
\text { Set-Up }\end{array}$ & Complicated & $\begin{array}{l}\text { Relatively Less } \\
\text { Complicated }\end{array}$ & None \\
\hline Hold and Shoot & Impossible & Possible & Possible \\
\hline Price & Expensive & Expensive & Relatively Cheap \\
\hline $\begin{array}{l}\text { Degree of } \\
\text { Precision }\end{array}$ & Most Excellent & Excellent & Relatively Excellent \\
\hline Strong Points & $\begin{array}{l}\text { This is being used } \\
\text { most universally } \\
\text { because it has an } \\
\text { excellent degree of } \\
\text { precision and it } \\
\text { makes few } \\
\text { mistakes. }\end{array}$ & $\begin{array}{l}\text { This is good for } \\
\text { getting dynamic } \\
\text { motions because } \\
\text { people can shoot } \\
\text { holding it. }\end{array}$ & $\begin{array}{l}\text { Right for simple } \\
\text { movements and } \\
\text { cheap }\end{array}$ \\
\hline Weak Points & $\begin{array}{l}\text { The system is } \\
\text { somewhat } \\
\text { complicated. Prices } \\
\text { range from cheap to } \\
\text { expensive and there } \\
\text { are flexibly various } \\
\text { products. }\end{array}$ & $\begin{array}{l}\text { Regarding space } \\
\text { restriction, this is } \\
\text { restricted by the } \\
\text { scope of an infrared } \\
\text { ray camera. }\end{array}$ & $\begin{array}{l}\text { Can be used for } \\
\text { simple movements } \\
\text { only }\end{array}$ \\
\hline
\end{tabular}

\section{B. Chroma Studio}

To do the Chroma Key work, a Chroma studio and a mat to do image fusion are necessary[8]. In general, shooting places which are mostly used for weather forecasts or vote counting become Chroma studios. A Chroma studio consists of Blue Box and lighting.

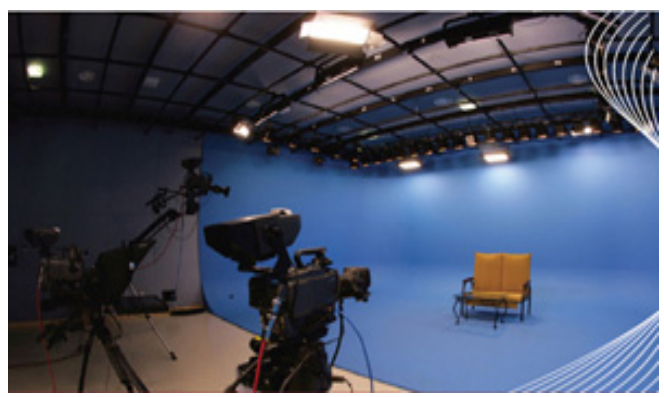

Fig. 1. Blue Screen

\section{Chroma Keyer}

Chroma Keyer is a core system of a virtual studio composing images with background images. The function of Chroma Keyer is usually loaded in ordinary switchers[9]. In addition, there are products with excellent performance, but virtual studios prefer independent Chroma Keyer.

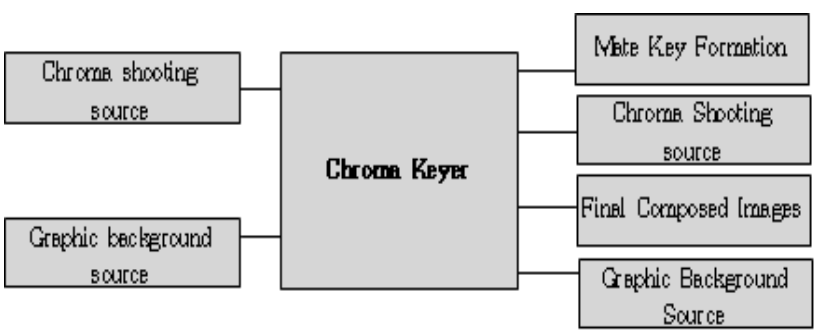

Fig. 2. Working processes at Chroma Keyer

\section{Graphic Workstation}

A virtual studio server is a system producing visuals (background set) at a virtual studio[10]. A graphic workstation is considered the most important element sending the real-time rendering value using values conveyed by a sensor to Chroma Keyer again.

\section{PRODUCTION ENVIRONMENT OF DOMESTIC BROADCASTERS' VIRTUAL STUDIOS}

\section{A. KBS}

KBS developed the "SMOCKEY (synchronized motion chroma-keyer)" system, a virtual studio which is a hardware processing type developed by its research institute using its technologies in 1995. After it, KBS also developed SMOCKEY II, a system whose performance was innovatively improved.

This system which consists of highly functional graphic computer and camera interface devices has simpler appearance and better functions and performance than the old version[11],[12]. After the SMOCKEY II system, KBS continuously conducted researches about a virtual studio using a graphic engine and developed a new product, Dream Set which could compete with an existing commercial virtual studio[7]. KBS currently is using Vizrt and Brainstorm software. As a virtual studio system which had been used for ballot counting began to be applied to History Special, the system was used for diverse programs[13].

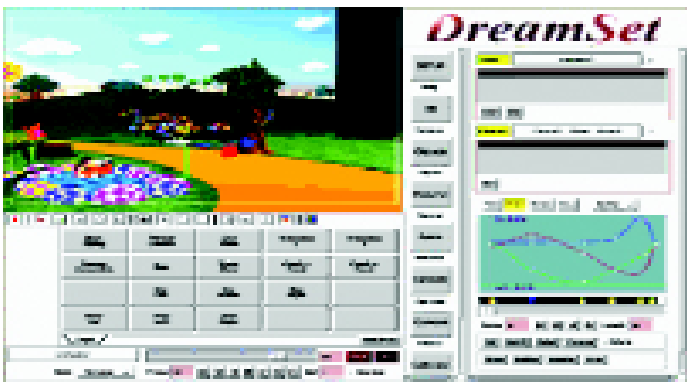

Fig. 3. KBS Dream Set 


\section{1) Structure and Characteristics of Virtual Studios}

KBS has three sets of virtual studios and one consists of TS-7 (Television Studio) which is a digital studio, News Studio and Annex Studio. TS-7 is as wide as about 60 pyeong $(10.7 \times 16 \times 5$ : studio, $9.7 \times 7 \times$ 3.7 : blue box), the News Studio is about 30 pyeong and the Annex Studio is about 32 pyeong including a control center.

\section{2) Information of Virtual Studio System and Present Conditions for Labor Force}

(A) Virtual studio program (brainstorm / vizrt)

Estudio of Brainstorm which is software being used by KBS has excellent the user interface that users easily can set various parameters for producing programs. VizVirtual Studio of Vizrt is attracting interests from operators by providing the intuitive and easy user interface environment at the Unix operation system.

\section{(B) Main computer (Onyx)}

KBS virtual studios used Onxy1 but sharply improved performance by adding Onxy 2. Virtual studios of KBS additionally was equipped with digital video input cards which could be input shadow videos captured by shadow cameras[14]. Those studios put model information and images on the memory, not hard discs, to form real-time videos, process $3 \mathrm{D}$ models and images using hardware boards and print them out using option boards for image printing.

\section{(C) Camera tracking system}

The virtual studio camera tracking system of KBS is mostly using the RADAMEC RP2 system. The camera tracking system can be divided into a remote control part and pedestal part. The TS-7 installed a remote part and pedestal part.

\section{(D) Chroma keyer (Ultimate-400, Ultimate-8, Ultimate-9)}

All three virtual studios of KBS use Ultimate. Most of the nation's broadcasting companies produce programs using the Ultimate Chroma Keyer. The digital Chroma Keyer is used for combining the actual images filmed by cameras to the virtual graphic background created by the main computer in real time.

\section{(E) Present conditions for labor force operation}

Three virtual studios of KBS are being operated by a significantly large staff. The TS-7 has a total of 7-8, including a technical director for each of MAYA, 3D MAX and 2D, two animators. The News Studio has four or five, a technical director, a 2D designer and three 3D designers. The Annex Studio for traffic broadcasting has four, two operators for 3D and $2 \mathrm{D}$ graphic operation, a system manager and a technical director.
TABLE 2

\section{COMPARISON DEPENDING ON WAYS OF} CAMERA TRACKING

\begin{tabular}{|c|c|c|c|}
\hline Division & \multicolumn{3}{|c|}{ KBS Virtual Studio } \\
\hline Division & $\begin{array}{c}\text { Special Video } \\
\text { Production Room } \\
\text { (TS-7) }\end{array}$ & $\begin{array}{l}\text { News Studio } \\
\text { (Newsroom) }\end{array}$ & Annex Studio \\
\hline $\begin{array}{c}\text { Graphic } \\
\text { Workstation }\end{array}$ & $\begin{array}{c}\text { Onyx II IR3 x } 2 \\
2 \text { GIVO, } 2 \text { DIVO }\end{array}$ & $\begin{array}{c}\text { Onyx II (2) } \\
1 \text { GIVO, } 1 \text { DIVO }\end{array}$ & $\begin{array}{l}\text { Onyx II IR3 x } 1 \\
2 \text { GIVO, } 2 \text { DIVO }\end{array}$ \\
\hline $\begin{array}{l}\text { Virtual } \\
\text { Software } \\
(\mathrm{S} / \mathrm{W})\end{array}$ & $\begin{array}{c}\text { Vizrt, } \\
\text { VR-STUDIO }\end{array}$ & Brainstorm & $\begin{array}{c}\text { Vizrt, } \\
\text { VR-STUDIO }\end{array}$ \\
\hline $\begin{array}{l}\text { Camera } \\
\text { Tracking } \\
\text { System }\end{array}$ & $\begin{array}{l}\text { RADAMEC, RP2 (2) } \\
\text { dolly possible } \\
\text { shotoku- VR, crane(1) } \\
\text { (TK-38LVR) }\end{array}$ & $\begin{array}{l}\text { RADAMEC, } \\
\text { RP2 (1) } \\
\text { 435VR (1), RP } \\
\text { 20,000 dolly } \\
\text { possible }\end{array}$ & $\begin{array}{c}\text { RADAMEC } \\
\text { RP2 (1) } 436 \mathrm{VR}\end{array}$ \\
\hline Chroma Keyer & $\begin{array}{l}\text { Ultimatte } 8(1) \\
\text { Ultimatte } 9(1)\end{array}$ & Ultimatte 9 (2) & $\begin{array}{c}\text { Ultimatte-9 (1) } \\
\text { Ultimatte-400 (1) }\end{array}$ \\
\hline EFP Camera & $\begin{array}{c}\text { Ikegami HK-377 } \\
\text { Ikegami } \\
\text { HK-388PW }\end{array}$ & $\begin{array}{c}\text { Ikegami } \\
\text { HK-388PW }\end{array}$ & $\begin{array}{l}\text { panasonic, AJ- } \\
\text { D910WAP }\end{array}$ \\
\hline PROMPTER & TOUCH-Q & TOUCH-Q & TOUCH-Q \\
\hline
\end{tabular}

\section{3) Present Situations of Program Production}

Programs produced at virtual studios of KBS include "Open the World of Children's Songs", "Weekend Notice", "Classic Odyssey" and "Secrets of Birth, Old Age, Sickness and Death." Following is basic set image files of "History Special[13]." and "Classic Odyssey[15]."

\section{(A) History Special}

This program uses two kinds of sets. One basic set is used for every episode regardless of the program theme. It is made to be suitable for the program concept and to effectively express historic maps, pictures, books and letters. The other set restores historic relics and includes towers, ancient structures, royal tombs or temples.

\section{(B) Classic Odyssey}

This program introduces classical music. Five virtual sets have been used and they were produced to make viewers feel comfortable because of characteristics of the program that it is aired at night and classical music is introduced during the program.
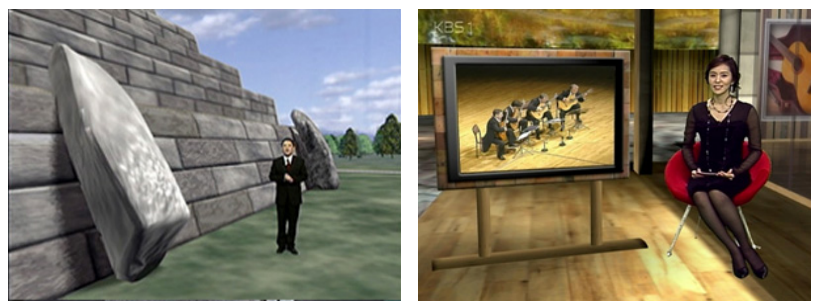

Fig. 4. Images of History Special, Classic Odyssey 


\section{B. $M B C$}

MBC has the Magic Studio system. This system uses DVG (digital video graphic), including two pipe printing Onyx2 which MBC bought from Silicon Graphic in 1999 as on-air graphic equipment[16]. MBC provides various $3 \mathrm{D}$ programs with a sense of realism through diverse event programs regarding elections and wars, as well as regular programs, such as those for children and entertainment, by realizing design and broadcasting progress with its technologies.

\section{1) Structure and Characteristics of MBC Magic Studio}

$\mathrm{MBC}$ is operating three mobile cameras using X-pecto of Orad, a infrared tracking system, as a camera tracking system. The MBC Magic Studio which is as wide as about 30 pyeong $(8 \times 12 \times 3.5)$ uses blue as its key color.

TABLE 3

ULTIMATTE VIDEO PAINT

\begin{tabular}{|c|c|c|c|}
\hline $\begin{array}{c}\text { Video levels when } 89.9 \% \\
\text { white is at } 100 .\end{array}$ & Red & Green & Blue \\
\hline \#05720 Rosco Ultimatte $®$ Blue & 22 & 40 & 82 \\
\hline \#05722Rosco Ultimatte $®$ Super Blue & 7 & 18 & 72 \\
\hline \#05721 Rosco Ultimatte $®$ Green & 29 & 84 & 36 \\
\hline
\end{tabular}

\section{2) Information of Magic Studio System and Present}

Conditions for Labor Force

MBC uses three cameras. Up to 24 infrared cameras attached to walls of the studio trace targets sticked to studio cameras. These cameras are used for extracting and using information on $3 \mathrm{D}(\mathrm{X}, \mathrm{Y}$ and $\mathrm{Z})$ locations of cameras, pans, tilts, roles, zoom and focus. MBC expresses virtual sets with clear pictures for broadcasting by loading Cyberset-O S/W. Main functions of graphic include to control objects to be before or after people and to materialize 3D charts and expression of Hangeul to display various data[17]. With Mapset, a mapping tool, textures which were rendered at 3D graphic packages and can be brought in and expressed in real time.

\section{TABLE 4}

\section{INFORMATION ON MBC MAGIC STUDIO} SYSTEM

\begin{tabular}{|c|c|c|c|}
\hline \multirow{2}{*}{ Division } & \multicolumn{3}{|c|}{ MBC Magic Studio } \\
\hline & Model & Use & Producer \\
\hline $\begin{array}{c}\text { Graphic } \\
\text { Worksttion }\end{array}$ & $\begin{array}{l}\text { Onyx2 2Pipes } \\
2 \text { GVO, } 4 \text { DIVO }\end{array}$ & For virtual studios & SGI \\
\hline $\begin{array}{l}\text { Virtual } \\
\text { Software }\end{array}$ & $\begin{array}{c}\text { Cyberset-O (2) } \\
\text { Cybergraphics (2) }\end{array}$ & $\begin{array}{l}\text { Software for operating } \\
\text { virtual studios }\end{array}$ & ORAD \\
\hline SURI & SURL 2.0 & $\begin{array}{l}\text { Software for creating 3D } \\
\text { charts and Hangeul }\end{array}$ & \\
\hline $\begin{array}{l}\text { Camera } \\
\text { Tracking } \\
\text { System }\end{array}$ & $\begin{array}{l}\text { XYNC, } \text { X-pecto dolly } \\
\text { possible } \\
24 \text { Surveillance Camera } \\
\text { support }\end{array}$ & $\begin{array}{l}\text { Capture value of camera } \\
\text { movements in real time }\end{array}$ & ORAD \\
\hline
\end{tabular}

\begin{tabular}{|c|c|c|c|}
\hline Camera & LDK-20P & Digital EFP camera & BTS \\
\hline $\begin{array}{c}\text { Digital } \\
\text { Chroma } \\
\text { Keyer }\end{array}$ & $\begin{array}{l}\text { Ultimatte } 8(2) \\
\text { Ultimatte } 9(2)\end{array}$ & $\begin{array}{c}\text { Top quality for combining } \\
\text { digital images }\end{array}$ & Ultimatte \\
\hline $\begin{array}{l}\text { Digital } \\
\text { VMU }\end{array}$ & DVS-1000 & $\begin{array}{l}\text { Digital VMU for switching } \\
\text { among multiple cameras }\end{array}$ & $\begin{array}{l}\text { Snell \& } \\
\text { Wilcox }\end{array}$ \\
\hline $\begin{array}{l}\text { Routine } \\
\text { Switcher }\end{array}$ & $\begin{array}{c}\text { Integrator } \\
32 \times 32 \text { Digital Routine }\end{array}$ & $\begin{array}{l}\text { Effective management } \\
\text { of digital signals }\end{array}$ & Leitch \\
\hline $\begin{array}{l}\text { CYBER } \\
\text { STUDIO }\end{array}$ & $\begin{array}{c}\text { Cyber Character S/W } \\
\text { (Clovis) }\end{array}$ & & Medialab \\
\hline $\begin{array}{l}\text { Special } \\
\text { Effect }\end{array}$ & Shake & Image effect & $\begin{array}{l}\text { Noting } \\
\text { Real }\end{array}$ \\
\hline $\begin{array}{l}\text { 3D Graphic } \\
\text { Production }\end{array}$ & MAYA / 3D Max / XSI & $\begin{array}{l}\text { Produce background and } \\
\text { provide source }\end{array}$ & Autodesk \\
\hline
\end{tabular}

TABLE 5

\section{RESENT CONDITIONS OF LABOR FORCE FOR MBC MAGIC STUDIO}

\begin{tabular}{|c|c|c|}
\hline MBC & $\begin{array}{c}\text { Present Conditions of } \\
\text { Management Labor Force }\end{array}$ & $\begin{array}{c}\text { Management } \\
\text { Staff }\end{array}$ \\
\hline Magic Studio & $\begin{array}{c}1 \text { technical director, 1 for system } \\
1 \text { for system development, } \\
2 \text { system operators and 2 designers }\end{array}$ & About 7 8 persons \\
\hline
\end{tabular}

\section{3) Present Conditions for Program Production}

Virtual studios of $\mathrm{MBC}$ has experienced three general elections and two presidential elections since 2000 in particular. In addition, $\mathrm{MBC}$ virtual studios can produce programs using the 3D-type chroma key technique getting out of 2D chroma key technique such as weather forecasts or relay seat screens of game programs. MBC Game made the first attempt in the history of broadcast by displaying games at virtual studios of its main building within the $3 \mathrm{D}$ space without spectators.

\section{(A) MBC Weather Center, Election Broadcasts}

The technique development team of MBC has developed election broadcast systems of MAGIC (MBC"s Advanced Generator for Information \& Communication MBC's state-ofthe-art election broadcast system) series since the 1992 presidential election. $\mathrm{MBC}$ is thought to have made the best use of weather-related virtual studios in the nation's broadcasters.
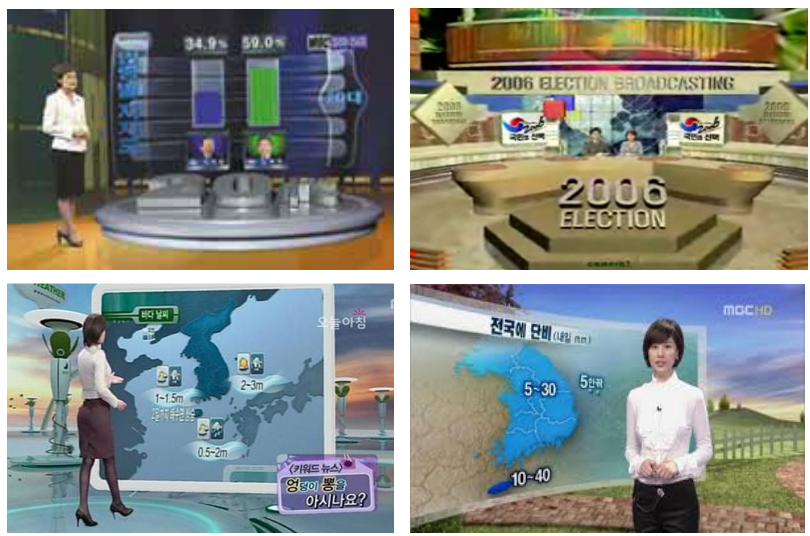

Fig. 5. MBC 2006' Election Broadcasts, Weather Center 


\section{(B) $M B C$ GAME}

Like Avatar, a film which recently has been a big issue, the 2010 'Nate MSL final' first introduced a new concept of image relay in a way to proceed with a game in the virtual space in accordance of the times when IMAX or $3 \mathrm{D}$ images created a sensation.

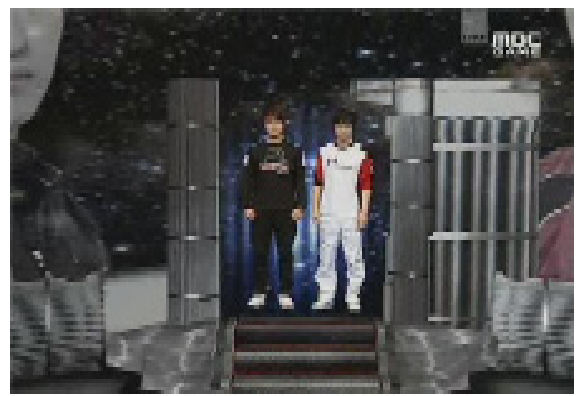

Fig. 6. 2010' nate MSL final

\section{SBS}

In the process of developing "Cyber Studio"' program, SBS provided various appearances to viewers through its accumulated technologies. SBS sent designers and programmers to the Israeli RT-SET and taught virtual technologies through local system education and focused on development of virtual sets after forming related team. In the 1997 presidential election, SBS prepared a 10m-high 250-pyeong studio for vote counting in CCMM Building. At the studio, about 50 officials, including an anchor, analyzers and persons in charge of collecting viewers' opinions, served the viewers so that they could see ballot counting at a glance[18].

\section{1) Information on Virtual Studios of $S B S$}

SBS used the Larus System for election broadcasts and increased stability and the speed of information conveyance forming dual Onyx which can energetically express advanced engineering graphic workstation, which is used for production of $3 \mathrm{D}$ graphic VIPON-5 that is used as ballot counting results and analysis data, and various $3 \mathrm{D}$ graphics.

\section{TABLE 6}

SBS INFORMATION OF VIRTUAL STUDIO SYSTEM

\begin{tabular}{|c|c|}
\hline Graphic Worksttion & Onyx2,1 GIVO, 1 DIVO,O2 \\
\hline Tracking System & Hawkeye(Fixed), dolly Impossible \\
\hline Crane & Sotoku(Use Radamec Tracking) \\
\hline Virtual Software & Vizrt, Viz Content Pilot \\
\hline Keyer & Ultimatte7 \\
\hline Software & Making Object : 3D MAX, XSI, MAYA \\
\hline
\end{tabular}

\section{2) Present Conditions for Program Production}

Virtual studios of SBS are producing various programs, including 8 O'Clock News, weather reports, cultural programs, entertainment \& sports. "Yasimmanman I Asked 10,000 People" (directed by Choi Yeong-in), in particular, showed "Paris Lovers Special," an exceptional studio talk summer feature which was attempted in the nation for the first time.
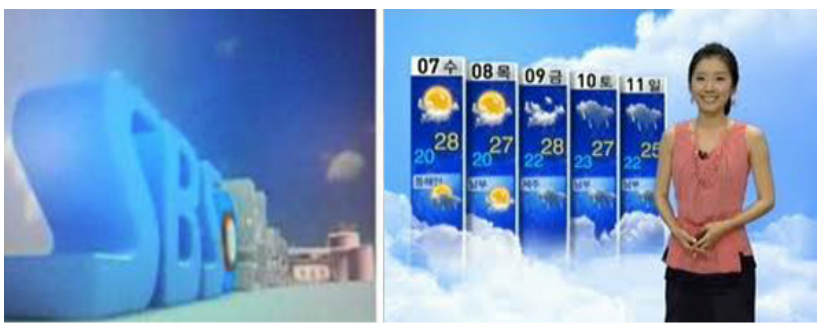

Fig. 7. SBS Weather \& Healthy Living

\section{DEVELOPMENT DIRECTIONS AND SUGGESTION}

Chapter III is about the environment of various virtual studio production and management of domestic broadcasting companies and a survey of programs representing those companies. Prior to producing programs using virtual studios, following four aspects should be considered.

\section{A. Expressional Aspects}

1) It is necessary to make a library of images, such as natural phenomena to make viewers feel a sense of reality.

2) Design should be made by combining creative ideas of the camera director, producer, technical staff and designers with features of virtual sets.

3) Diversity of images should be pursued to produce an atmosphere with a sense of reality using colors and tones of background sets.

4) Lighting and sets should be formed to display a sense of unity. Those sets should not make a sense of difference with real sets and should make a broad use of the width of expression.

\section{B. Technical Aspects}

1) A number of cameras should be applied to programs easily. All camera techniques used for existing sets should be applied.

2) A number of tracking systems should be made easily.

3) Techniques to process visual effects in real time should be developed. Only when real-time rendering processing techniques develop in composition of a large number of images, various virutal realities can be materialized. 
4) Investment and researches should be made in order to develop virtual studio software for which the nation's broadcasting companies depend on foreign countries.

\section{Cultural Aspects}

1) In virtual space production, visual contents of programs should not have excessive illusions and distorted truth.

2) A virtual set designer should make colors and atmosphere suitable for the time of program airing.

3) Virtual reappearance should make truth-based expressional verification.

\section{Economical Aspects}

1) Accumulated data should be stored and backed up to be used for other programs.

2) Interface should be used for used data after arranging them by field so that they can be used any time they are necessary to reduce costs needed for production time.

3) As many as contents should be secured to replace expensive real sets with virtual sets.

\section{E. Spatial Aspects}

1) We need to analyze and categorize programs to overcome environmental obstacles of virtual sets.

2) We should review the analyzed programs to see if space is well exploited for the use of virtual sets.

3) Designers should have regard to camera's moving lines and subjects' movements when making the virtual sets.

Development of virtual studios is getting the spotlight as a state-of-the-art field to bring innovation to the program production mechanism. As shown by domestic cases of virtual studios, virtual studios have unlimited values of use for producing programs which can't be materialized with images, such as "History Special" or "Weather Reports." Virtual studio production processes should make image sets with producers using $2 \mathrm{D}$ or $3 \mathrm{D}$ graphics considering each aspect suggested above and should solve technical problems with engineers operating virtual sets.

It is the most important part in composition for set producers to make programs by making accurate communication[19] so that images of the foreground and background can match well each other.

\section{CONCLUSIONS}

This paper introduces systems and technical elements necessary for virtual studio production and representative programs which are being produced through domestic present conditions of virtual studios. Techniques of virtual studios are continuously development but the reality is that programs which we are watching are being used in a limited way. Broadcasting companies currently make various set designs and props to prepare physical sets.

The environment for set production shows that physical time and workers needed for studio setting takes high costs. As virtual studio set production needs a small number of persons and uses computer software, restriction of direction space and time greatly reduces. In addition, direction of virtual studio programs can expected different visual effects from existing studio production because of creative sets. Small broadcasting studios spend high costs to secure the space for studios in reality.

As they have no space to use physical sets, the environment of virtual studio production is desperately needed. Considering such circumstances, the necessity of virtual studios is closely connected with the practical production environment. Since broadcasting companies introduced virtual studios, they have made much efforts to overcome technical assistance or expressional limitation. They, however, haven't made great achievement in terms of utilization of virtual studios.

As far as the production environment of virtual studios which we know is concerned, we can see that we should conduct researches to analyze those studios more minutely to utilize them. If we use advantages of virtual studios, we will be able to make a new access to utilization of creative programs. In this paper, I suggested directions for development of virtual studios through expressional, technical, cultural and economical aspects in virtual studio production processes. Image production experts should try to have a keen interest in virtual studios and researches should be conducted about a new attempt of virtual sets. By producing programs through these aspects, production environments can be diversified and systematic systems will be newly established. Additionally, the outlook of the nation's virtual studios is expected to be brighter.

\section{REFERENCES}

[1] Moshe, Moshkovitz, The Virtual Studio, (BBC Danny Popkin, 2000), p.1.

[2] Simon Gibbs, op. cit., 1998, p.20.

[3] Lee jong Yun, "Virtual Studio Light" Korea Society Broadcast Engineers Magazine 1998.

[4] Kang Myung Hoon, "The Reality Study on the Application of Virtual Reality Appeared in TV Broadcasting" The Graduate School of Advertising \& Public Relations Hong Ik University, 2001.

[5] Sim Jae Cheon "A Study on Current Situation of Television Station Virtual Studio", The Graduate School of Mass Communication Chung-Ang University, 2003, p79

[6] Yoon, Jin-Hee, "A study on Colors of the Broadcasting Stage Space", Master's Thesis for Graduate School of Design Ewha Womans University, 2007.

[7] Lee Joo-yeon 'A study on literature related with virtual studio' Master's Thesis for Graduate school of Department of Mass Communication, Chung-Ang University, 2003, p.10.

[8] Gregory Pyros, "Designing Virtual Sets", Computer Graphics World, June 1998. 
[9] Go Hee-dong "Virtual Studio Technology", Broadcasting and Technology, No 3, (Korea Broadcasting Engineer \& Technicians Association. ,1997)

[10] Simon Gibbs, "Virtual Studio", IEEE Multimedia, 1998 JanuaryMarch, p.18.

[11] Cho Mun-jae "SMOKEY 2 System and Election Broadcast for 15th Assemblymen", (Broadcast and Techniques), No. 48,(Seoul: Korea Broadcasting Engineers \& Technicians Association 1997), pp.84-91

[12] Lee Chung Ku, "Virtual Studio", Broadcasting and Technology, No 89 (Seoul : Korea Broadcasting Engineer \& Technicians Association., 2003)

[13] http://www.kbs.co.kr/history/index.shtml

[14] Hong In-gi. "Reinforcement of Virtual Studio System and Expected Effect", 「Broadcast Technique Information $\lrcorner$, Serial Number 59 (Seoul: KBS, 2001), p.193

[15] http://www.kbs.co.kr/1tv/sisa/classic/

[16] www.hdmbc.com/broad tech.

[17] Park Chan-yeol, "Understanding of Virtual Studio", 「Video Plus $\lrcorner$, (Seoul: Yeoul Media 2000), p.107.

[18] www.sbs.co.kr/family/SBS-tech/item 1.html.

[19] Paik, hwa -lim, "A study of the expression of space in virtual studio set”, Master's Thesis for Graduate school of Hong - Ik university 2004.

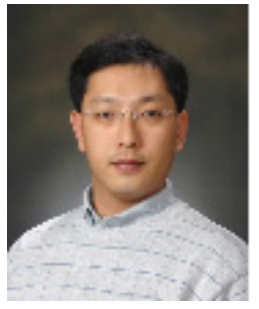

Jun-Sang Lee Born in 1972, Busan, Korea. He received M.S. degree in Digital Media Engineering, Dong-Eui University, Korea, in 2009. Doctoral course for Digital Media Engineering, Dong-Eui University 2010.

Part-time lecturer for Department of Digital Contents Engineering, Dong-Eui University 2010. His research interests are in 3D Animation, Motion Graphics, film editing.

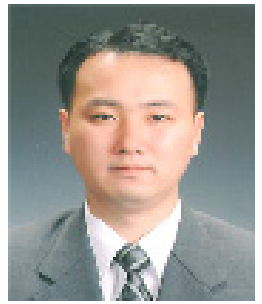

Sungdae Park Born in 1974. He received B.S., M.S. and Ph.D. degree in Multimedia Eng., Dong-eui University, Korea, in 2002, 2005 and 2008 , respectively. Since Feb. of 2008, he has joined the Dept. of Digital Contents Eng., Dong-eui University, where he is currently a fulltime lecture. His research interests are digital design \& nonlinear editing, neural networks, pattern recognition and image processing.

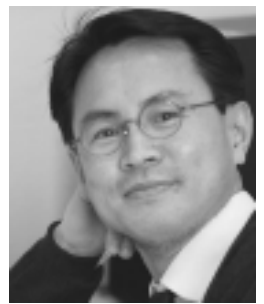

Kim Cheeyong Born in 1964, Pohang, Korea. He received the Ph.D.,degree in Computational Physics from Inje University, Republic of Korea, in 2000. He worked at Inje University, Busan College from 1991 2002 and at Dongseo University from 2003 2005. In 2006, he joined the DongEui University, where he is an associate professor. His research interests are in 3D Animation, Multimedia design and VR Web 3D Contents Design, Fractal \& Chaos design, Conceptual Design. 